\title{
Impact of the 2015 Migration Crisis on German Food Security
}

\author{
Nikita S. Ivannikov*, Sergey A. Mungalov \\ Peter the Great St. Petersburg Polytechnic University, St. Petersburg, Russian Federation; *ivannikov. \\ n78@gmail.com
}

\begin{abstract}
The article considers some social and political consequences of the migration crisis of 2015 in the Federal Republic of Germany, as well as its impact on food security in the country. In order to assess the latter, the statistical data related to socioeconomic factors important for food security were analyzed. Both the problems faced by migrants and their positive contribution to the agricultural sector, as well as the methods taken by Germany to improve the situation of migrants were highlighted. The most important factor influencing food security in the conditions of sharp population growth caused by the migration crisis is adaptation, since both the further involvement of migrants in the economic life of the country and their further prosperous existence depend on its success. The effectiveness of measures taken by the German government for adaptation of migrants ensured a significant contribution to the preservation of the former level of food security in the changed conditions of the state.
\end{abstract}

Keywords: Germany, migration, food security, migration crisis of 2015, adaptation of migrants

For citing: Ivannikov N.S., Mungalov S.A. Impact of the 2015 Migration Crisis on German Food Security // Administrative consulting. 2021. N 4. P. 146-152.

\section{Влияние миграционного кризиса 2015 года на продовольственную безопасность Германии}

\author{
Иванников Н. C. *, Мунгалов С. А.
}

Санкт-Петербургский политехнический университет Петра Великого, Санкт-Петербург, Российская Федерация; *ivannikov.n78@gmail.com

\section{PЕФЕРАТ}

В статье рассматриваются некоторые социальные и политические последствия миграционного кризиса 2015 г. в ФРГ, а также его влияние на продовольственную безопасность в стране. Для оценки последних были проанализированы статистические данные, касающиеся социально-экономических факторов, имеющих важное значение для продовольственной безопасности. Были отмечены как проблемы, с которыми сталкиваются мигранты, так и их позитивный вклад в сельскохозяйственный сектор, а также методы, принятые Германией для улучшения положения мигрантов. Важнейшим фактором, влияющим на продовольственную безопасность в условиях резкого роста населения, вызванного миграционным кризисом, является адаптация, поскольку от его успеха зависит как дальнейшее вовлечение мигрантов в экономическую жизнь страны, так и их дальнейшее благополучное существование. Эффективность принимаемых правительством Германии мер по адаптации мигрантов обеспечила значительный вклад в сохранение прежнего уровня продовольственной безопасности в изменившихся условиях государства.

Ключевые слова: Германия, миграция, продовольственная безопасность, миграционный кризис 2015 г., адаптация мигрантов

Для цитирования: Ivannikov N.S., Mungalov S. A. Impact of the 2015 Migration Crisis on German Food Security // Управленческое консультирование. 2021. № 4. С. 146-152. 


\section{Introduction}

The problems of hunger and food security on a global scale are still one of the main and urgent problems of our time. Their unresolved nature comes down to a variety of causes beyond the agricultural sector's production scale. Food security has economic and socio-political connotations, as it directly depends on the ability to ensure human rights to a healthy and fulfilling life. This aspect of the problem becomes particularly important in the modern world, particularly in view of the increasing scale of migration processes.

In reality, hunger is not only a physiological problem for certain groups of the planet's population, but is also closely linked to certain socio-political and economic phenomena, such as increased crime and homelessness and a decline in human capital. These factors can indeed have a significant impact on the general welfare of the state and its sovereignty. The topic of food sovereignty, which may be significantly affected by active migration processes, is currently being updated in the scientific literature. Issues related to ensuring food security in the context of large-scale migration of various kinds are undoubtedly relevant to modern scientific thought. This article discusses the impact of the 2015 migration crisis on Germany's food security. At the peak of the migration crisis in Germany, according to the chosen political credo "Germany is ready to accept all" ${ }^{1}$ - indeed accepted the largest number of migrants ${ }^{2}$. The situation faced by the German government is an unimaginable flow of people who came with a completely different culture, without knowledge of the local language, but who needed support in many areas of life. All this caused an excessive strain on the social structures of the state.

These massive changes in the composition of the population have affected many areas of society, and it is interesting to see how this has affected German food security. The purpose of this work is to identify the impact of the migration crisis in 2015 on food security of Germany, which is one of the most developed and stable countries in the world. The experience of the actions taken by Germany to solve this problem can be very useful for understanding what actions in such situations can be most productive.

\section{Materials and methods}

In order to assess the possible impact of the 2015 migration crisis on German food security, it is necessary to take into account indicators that have a direct impact on hunger, such as population growth, poverty levels, unemployment, GDP per capita and food security index. The main method of research is comparative analysis.

\section{Results}

In general, when speaking about the relationship between migration processes and food security, modern research indicates that the former most often have a positive impact on the latter. This is mostly true for voluntary migration, where both the donor country and the recipient country are most likely to experience positive effects from migrant labor activity. However, forced migration can also have a stimulating effect on the state of food security, even if not to such a great extent (mostly because of vulnerability and

\footnotetext{
${ }^{1}$ Fomina D.D. Europe's migrant crisis: Germany's position // Actual problems of modern international relations. 2016. № 7 [Electronic resource]. URL: https://cyberleninka.ru/article/n/sovremennyymigratsionnyy-krizis-v-evrope-pozitsiya-germanii (accessed: 11.05.2020). P. 101. (In Rus).

${ }^{2}$ Bocharnikov I. V. Social and humanitarian aspects of the European migration crisis // Locus: people, society, cultures, meanings. 2016. № 4 [Electronic resource]. URL: https://cyberleninka. $\mathrm{ru} /$ article/n/sotsialnye-i-gumanitarnye-aspekty-evropeyskogo-migratsionnogo-krizisa (accessed: 11.05.2020). C. 81. (In Rus).
} 
exposure of migrants to hunger and other socio-economic problems) ${ }^{1}$. Some studies have identified migrant labour in agriculture as a key mechanism for ensuring food security ${ }^{2}$. Among the positive factors influencing the qualitative indicators of agricultural productivity are the diverse experience of migrants in this area, the synergetic effect of existing labor skills and those acquired during adaptation ${ }^{3}$.

When discussing the consequences of the migration crisis in Germany, some of its peculiarities should be taken into account. In its process, Germany's bureaucratic apparatus failed to cope with its own system that initially migrants are registered and "assigned" to a certain land, each of which has its own limit on the number of people received, and only after that they submit an official request. As a result the executive authorities were heavily loaded with the flow of applications and therefore the asylum applications sometimes lay for months ${ }^{4}$. Therefore, many refugees did not obtain such legal status, or did not apply and were lost in the country. This had a negative impact on the social status of migrants, their financial situation and, as a consequence, on their ability to provide food for themselves.

The following tables 1-4 show important indicators for Germany's food security that are subject to change due to the migration crisis.

Based on the above statistics, it can be concluded that significant social and economic aspects of life in Germany have not undergone significant changes due to the migration crisis, moreover, Germany has managed to maintain a positive development dynamics. It should also be noted that the monetary subsidies allocated for the needs of migrants do not have a long-term negative impact on the economy of the country, as these funds will be returned to the economy through private enterprises engaged in the production of consumer goods ${ }^{5}$.

In addition to statistical data demonstrating the absence of negative impact of migration crisis on significant socio-economic indicators, it should be noted the positive impact of migrants on the agricultural sector. Involvement of migrants in agricultural activity is really justified, relevant and effective ${ }^{6}$, and limitations in this particular sphere may be rather counterproductive ${ }^{7}$. One of the reasons for this is that many of the migrants are willing to take up hard physical labor, which is not popular among the local population ${ }^{8}$.

\footnotetext{
1 Kate Ambler, Alan de Brauw. How migration benefits economies and food security // IFPRI [Electronic resource]. URL: https://www.ifpri.org/blog/how-migration-benefits-economies-and-foodsecurity (accessed: 11.08.2020).

2 Migrants key in developing European farming, food safety // Infomigrants [Electronic resource]. URL: https://www.infomigrants.net/en/post/9654/migrants-key-in-developing-european-farmingfood-safety (accessed: 11.11.2020).

${ }^{3}$ Natasha Clocker, Lesley Head, Olivia Dun, Tess Spaven. Experimenting with agricultural diversity: Migrant knowledge as a resource for climate change adaptation // Sciencedirect [Electronic resource]. URL: https://www.sciencedirect.com/science/article/abs/pii/S074301671730116X (accessed: 11.11.2020).

${ }^{4}$ Stefan Trines. Lessons from Germany's Refugee Crisis: Integration, Costs, and Benefits // World Education News \& Reviews [Electronic resource] . URL: https://wenr.wes.org/2017/05/ lessons-germanys-refugee-crisis-integration-costs-benefits (accessed: 11.08.2020).

5 Deutsche Wirtschaft im ersten Quartal um 0,7 Prozent gewachsen // Welt [Electronic resource]. URL: https://www.welt.de/newsticker/dpa_nt/infoline_nt/schlaglichter_nt/article155311522/DeutscheWirtschaft-im-ersten-Quartal-um-0-7-Prozent-gewachsen.html (accessed: 11.11.2020)

6 Philip L. Martin. Migrant Workers in Commercial Agriculture // ILO [Electronic resource]. URL:https://www.ilo.org/wcmsp5/groups/public/---ed_protect/---protrav/---migrant/documents/publication/wcms_538710.pdf (accessed: 11.11.2020).

7 Working document on migration and wage-labour. Migration and rural areas in Europe. European Coordination via Campesina ECVC, April 2017 [Electronic resource]. URL: https://www.eurovia.org/ wp-content/uploads/2016/03/ECVC-Document-on-Migration-and-Rural-Labour-2017.pdf (accessed: 11.11.2020).

8 „Forscher: Flüchtlingsintegration schneller als erwartet“ // DW [Electronic resource]. URL: https:// www.dw.com/de/forscher-flüchtlingsintegration-schneller-als-erwartet/a-49904631 (accessed: 11.11.2020).
} 
Population of Germany in millions of people from 2015 to 2020 *

\begin{tabular}{|l|c|c|c|c|c|c|}
\hline \multicolumn{1}{|c|}{ Population } & $\mathbf{2 0 1 4}$ & $\mathbf{2 0 1 5}$ & $\mathbf{2 0 1 6}$ & $\mathbf{2 0 1 7}$ & $\mathbf{2 0 1 8}$ & $\mathbf{2 0 1 9}$ \\
\hline Overall population & 80,8 & 81,2 & 82,2 & 82,5 & 82,8 & 83,2 \\
\hline German population & 73,7 & 73,5 & 73,4 & 73,2 & 73 & 72,8 \\
\hline Non-citizens & 7,1 & 7,7 & 8,8 & 9,3 & 9,8 & 10,4 \\
\hline
\end{tabular}

*Bevölkerung auf Grundlage des Zensus 2011 nach Geschlecht und Staatsangehörigkeit im Zeitverlauf // Statistisches Bundesamt [Electronic resource]. URL: https://www.destatis.de/DE/Themen/GesellschaftUmwelt/Bevoelkerung/Bevoelkerungsstand/Tabellen/liste-zensus-geschlecht-staatsangehoerigkeit.html (accessed: 11.11.2020).

Table 2

Economic indicators of GDP in billion US dollars and GDP per capita in US dollars of Germany in the period from 2015 to 2020*

\begin{tabular}{|l|c|c|c|c|c|c|}
\hline \multicolumn{1}{|c|}{ Indicator } & $\mathbf{2 0 1 5}$ & $\mathbf{2 0 1 6}$ & $\mathbf{2 0 1 7}$ & $\mathbf{2 0 1 8}$ & $\mathbf{2 0 1 9}$ & $\mathbf{2 0 2 0}$ \\
\hline GDP & 3357,926 & 3468,896 & 3681,303 & 3965,565 & 3861,550 & 3780,553 \\
\hline GDP per capita & 41107 & 42124 & 44537 & 47832 & 46472 & 45466 \\
\hline
\end{tabular}

*GDP and GDP per capita report // IMF: World Economic Outlook (WEO) Database [Electronic resource]. URL: https://www.imf.org/en/Publications/WEO/weo-database/2020/October/weo-report?c=134,\&s= NGDP_R,NGDP_RPCH,NGDP,NGDPD,PPPGDP,NGDP_D,NGDPRPC,NGDPRPPPPC,NGDPPC,NGDPDPC, PPPPC,$\& s y=2015 \&$ ey $=2020 \& s s m=0 \& s c s m=1 \& s c c=0 \& s s d=1 \& s s c=0 \& s i c=0 \&$ sort $=$ country\&ds $=. \& b r=1$ (accessed: 13.10.2020).

Table 3

Poverty rate in EU countries and Germany in the period from 2014 to 2020, $\%$ of population*

\begin{tabular}{|l|l|l|l|l|l|l|}
\hline \multicolumn{1}{|c|}{ Countries } & $\mathbf{2 0 1 4}$ & $\mathbf{2 0 1 5}$ & $\mathbf{2 0 1 6}$ & $\mathbf{2 0 1 7}$ & $\mathbf{2 0 1 8}$ & $\mathbf{2 0 1 9}$ \\
\hline Germany & 20,6 & 20,0 & 19,7 & 19,0 & 18,8 & 17,4 \\
\hline EU & 24,4 & 23,7 & 23,5 & 22,4 & 21,6 & 21,1 \\
\hline
\end{tabular}

${ }^{*}$ Eurostat. People at risk of poverty or social exclusion by income quintile and household type [Electronic resource]. URL: https://ec.europa.eu/eurostat/databrowser/view/ilc_peps03/default/ table?lang=en (date accessed: 11.11.2020).

Table 4

Unemployment rate in Germany in a percentage of population in the period from 2014 to 2020 , \% of population*

\begin{tabular}{|c|c|c|c|c|c|c|c|}
\hline $\begin{array}{c}\text { Percentage } \\
\text { of unemployed }\end{array}$ & 2014 & 2015 & 2016 & 2017 & 2018 & 2019 & 2020 \\
\cline { 2 - 8 } & 6,7 & 6,4 & 6,1 & 5,7 & 5,2 & 5 & 4,5 \\
\hline
\end{tabular}

*Arbeitslosenquote in Deutschland im Jahresdurchschnitt von 2004 bis 2020 // Statista [Electronic resource]. URL:https://de.statista.com/statistik/daten/studie/1224/umfrage/arbeitslosenquote-indeutschland-seit-1995/ (accessed: 11.08.2020).

In addition, migrant employment itself has a beneficial impact on their economic status and, as a result, on their ability to feed themselves. 
Moreover, the actual experience shows that without their participation it becomes difficult to implement the existing plans in the field of agriculture ${ }^{1}$. This is especially evident now, when due to the coronavirus pandemic the traditional seasonal migration of agricultural workers is impossible. In this context the migration inflow of population is a significant support, which is confirmed by real practice. In 2020, even illegal and partially documented migrants were allowed to work in the agricultural sector ${ }^{2}$. This proves that the effective use of such a tool is a feasible practice capable of solving existing problems.

When analyzing Germany's food security indicators directly over the period under study, Global Productive Safety Index should be referred to. It should be noted that Germany is one of the leading countries of the index, and its overall situation has not changed since pre-crisis 2014. Until 2018, Germany was in the top ten on this index (eleventh place since 2018). The indicator has fallen only twice - in 2016 and in 2019. It would seem logical to assume that the fall in 2016 is due to the migration crisis, but the decline in the overall results is observed among all participants in the rating, so to explain this for Germany separately seems untenable, especially since the rating itself notes the overall level of growth in food security on a global scale ${ }^{3}$.

The circumstances of migrants' lives, which are aggravating factors for the food problem, should also be considered.

One of them is the need to adapt to the local food market. In unfamiliar circumstances, it is often more difficult for people to find traditional products and prepare food. Restructuring this sphere of human life in the short term (if further adaptation is successful) may have a negative impact on food security in the population under consideration ${ }^{4}$. Diet changes and other changes in food behavior can also have a negative impact on human health and, consequently, on the quality of human capital. Among migrants, cardiovascular diseases and diabetes are common. Another problem may be the situation faced by the second generation of emigrants to the country. Despite the higher standards of living instilled during adaptation, children of migrants may have difficulty implementing them because of the generally low financial security that is traditional for such communities. This can lead to problems not only of a physiological but also of a psychological nature.

Another phenomenon that negatively affects the situation of migrants and, as a consequence, their food supply is discrimination in the labor market.

Currently there are quite a lot of people with migration background in Germany, about

${ }^{1}$ Dobrynin $V$. Wonder Season: Europe may be left without harvest // Izvestia [Electronic resource]. URL: https://iz.ru/1004071/vladimir-dobrynin/sezon-chudes-evropa-mozhet-ostatsia-bez-urozhaia (accessed: 19.10.2020). (In Rus).

2 "Germany to allow asylum seekers to work in agriculture until October" // Infomigrants [Electronic resource]. URL: https://www.infomigrants.net/en/post/24276/germany-to-allow-asylumseekers-to-work-in-agriculture-until-october (accessed: 19.10.2020).

${ }^{3}$ EIU Global food security index 2014. An annual measure of the state of global food security. The Economist Intelligence Unit, 2014. P. 13; ElU Global food security index 2015. An annual measure of the state of global food security. The Economist Intelligence Unit, 2015. P. 10; EIU Global food security index 2016. An annual measure of the state of global food security. The Economist Intelligence Unit, 2016. P. 9; EIU Global food security index 2017. An annual measure of the state of global food security. The Economist Intelligence Unit, 2017. P.9; EIU Global food security index 2018. An annual measure of the state of global food security. The Economist Intelligence Unit, 2018. P. 30; Global Food Security Index // The Economist Intelligence Unit Limited, 2019 [Electronic resource]. URL: https://foodsecurityindex.eiu.com/Index (accessed: 19.08.2020).

${ }^{4}$ Food \& Migration: Understanding the geopolitical nexus in the Euro-Mediterranean // Macrogeo [Electronic resource]. URL: https://www.barillacfn.com/m/publications/food-and-migration.pdf (accessed: 17.06.2020). 
21 million ${ }^{1}$ (about a quarter of the country's population) ${ }^{2}$. Of course, not all of them, as well as most of those who arrived in 2015 are not highly qualified professionals, but the labor market requires not only the latter. However, candidates with non-German names and foreign origins face a much lower return on their CVs than their German peers, which is especially evident in small and medium-sized businesses ${ }^{3}$. Despite seemingly encouraging evidence that companies' discriminatory policies have weakened in recent years ${ }^{4}$, problem is still present though in different scale. This happens sometimes in spite of real successes in the education of immigrants, even at school level ${ }^{5}$.

Thus, it can be noted that one of the main problems faced by migrants and refugees who arrived in Germany as a result of the migration crisis in 2015 is related to adaptation processes. Their success determines the future fate of those who arrived in the country, as well as the role they will play in the country's economy and the level of human capital.

It is necessary to note successful experience of Germany in adaptation of migrants. Germany has long been a very attractive destination for migration, including successful and effective integration programs that facilitate intercultural adaptation. These include such programs as:

1. Conducting prevention campaigns to combat prejudice and discrimination.

2. Programs for the harmonization of intercultural relations ${ }^{6}$.

3. Programs to provide social security for basic living and adaptation needs.

4. Teaching German language.

5. Compulsory school education for children of migrants, as well as adaptation classes for adolescents or children in need.

6. Organization of intercultural events, such as Interkulturelle Woche ${ }^{7}$.

Implementation of such programs helped both to successfully integrate migrants into German society and to prepare the latter for new life realities ${ }^{8}$.

\section{Discussion}

To begin with, it is worth noting that Germany is still among the leaders in ensuring food security of the population according not only to the hunger index, but also, in particular, in the FAO rating. The organization uses a separate classification according to the

\footnotetext{
1 Jede vierte Person in Deutschland hatte 2018 einen Migrationshintergrund // Statistisches Bundesamt. 2019 [Electronic resource]. URL: https://www.destatis.de/DE/Presse/Pressemitteilungen/2019/08/PD19_314_12511.html (accessed: 18.04.2020).

2 Bevölkerung in Deutschland: 83,0 Millionen zum Jahresende 2018 // Statistisches Bundesamt. 2019 [Electronic resource]. URL: https://www.destatis.de/DE/Presse/Pressemitteilungen/2019/06/ PD19_244_12411.html (accessed: 18.04.2020).

${ }_{3}$ Schneider J., Yemane R. Ethnische Diskriminierung, «Störfaktor im Integrationsprozess. Empirische Erkenntnisse» // Bundeszentrale für politische Bildung. 2014. S. 3 [Electronic resource]. URL: https:// www.bpb.de/apuz/180856/ethnische-diskriminierung-stoerfaktor-im-integrationsprozess? $\mathrm{p}=2$ (accessed: 19.04.2020).

${ }^{4}$ Hille P. OECD: Integration von Migranten schreitet voran // Deutsche Welle. 2019 [Electronic resource]. URL: https://p.dw.com/p/3BdV6 (accessed: 19.11.2020).

5 lbid.

${ }^{6}$ Burdo V. V. Modern migration policy of Germany: state and problems // International student scientific bulletin. 2018. № 1 [Electronic resource]. URL: http://eduherald.ru/ru/article/view?id=18036 (accessed: 30.09 .2020 ).

${ }^{7}$ Burdo V. V. Modern migration policy of Germany: state and problems // International student scientific bulletin. 2018. № 1 [Electronic resource]. URL: http://eduherald.ru/ru/article/view?id=18036 (accessed: 30.09.2020).

${ }^{8}$ Forscher: Flüchtlingsintegration schneller als erwartet // DW [Electronic resource]. URL: https:// www.dw.com/de/forscher-flüchtlingsintegration-schneller-als-erwartet/a-49904631 (accessed: 11.09.2020).
} 
value of the food security index. According to this classification, Germany is classified as a country where consumption is at or above the required level, part of the food is exported, and less than five percent of the population is food insecure in terms of quality or quantity ${ }^{1}$.

Despite the obviously stable and good position of both Germany and most EU member states, domestic policy, as well as that of the EU as a whole, must take into account the food implications of continued migration. Such phenomena as stereotypical thinking, discrimination and cultural misunderstandings must be overcome in order to successfully meet the social dimension of food security. This aspect cannot be implemented solely within the agricultural sector, but it needs to be coordinated across the different spheres of life, and the synergies between which can produce the necessary results.

\section{Conclusion}

It may be noted that despite the migration crisis in 2015, the actions taken by the German government have had a positive impact on the resolution of problems arising from the crisis. This, naturally, includes the measures taken related to the adaptation of migrants and their full involvement in the country's life. It is also highly relevant to continue the policy of non-discrimination, which raises the overall standard of living of immigrants, which Germany is successfully coping with.

All of these measures have had a positive impact on the overall state of food security, and have also enabled Germany to cope with the difficulties caused by the crisis in 2015 and to maintain food security at pre-crisis levels.

\section{About the authors:}

Nikita S. Ivannikov, assistant lecturer, Higher School of International Relations, Institute of Humanities, Peter the Great St. Petersburg Polytechnic University (St. Petersburg, Russian Federation), PhD in Political Science; ivannikov.n78@gmail.com.

Sergey A. Mungalov, student, Higher School of International Relations, Institute of Humanities, Peter the Great St. Petersburg Polytechnic University (St. Petersburg, Russian Federation); serzh.mungalov@yandex.ru

\section{Об авторах:}

Иванников Никита Сергеевич, ассистент Высшей школы международных отношений Гуманитарного института Санкт-Петербургского политехнического университета Петра Великого (Санкт-Петербург, Российская Федерация), кандидат политических наук; ivannikov. n78@gmail.com

Мунгалов Сергей Александрович, студент Высшей школы международных отношений Гуманитарного института Санкт-Петербургского политехнического университета Петра Великого (Санкт-Петербург, Российская Федерация); serzh.mungalov@yandex.ru

\footnotetext{
${ }^{1}$ The State of Agricultural Commodity markets. Food self-sufficiency and international trade: a false dichotomy? Fao, 2015 [Electronic resource]. URL:http://www.fao.org/3/a-i5222e.pdf (accessed: 24.11.2020).
} 